\title{
The decline of the Nile crocodile population in Loskop Dam, Olifants River, South Africa
}

\author{
Hannes Botha ${ }^{1,2 *}$, Wouter van Hoven ${ }^{1}$ and Louis J Guillette $\mathrm{Jr}^{3,4}$ \\ ${ }^{1}$ Centre for Wildlife Management, University of Pretoria, Pretoria, 0002, South Africa \\ ${ }^{2}$ Mpumalanga Tourism and Parks Agency, Scientific Services, PO Box 1250, Groblersdal, 0470, South Africa \\ ${ }^{3}$ Department of Biology, University of Florida, Gainesville, Florida, USA \\ ${ }^{4}$ Department of Paraclinical Sciences, Faculty of Veterinary Science, University of Pretoria, \\ Private Bag X04, Onderstepoort, 0110, South Africa
}

\begin{abstract}
The apparent decline in the number of Nile crocodiles present in the Loskop Dam prompted a study to determine the number, size and distribution of Nile crocodiles now present in the reservoir. The number of crocodiles in the Loskop Dam was surveyed using aerial counts and spotlight counts. Surveys revealed the presence of a very low total number of crocodiles and also a poor distribution of crocodiles in the different size classes over almost 30 years since 1981. Eight surveys carried out between 2001 and 2010 revealed that the distribution pattern of crocodiles in the Loskop Dam did not vary between winter and summer. These distribution patterns indicate that crocodiles occur most frequently in the eastern and western inlets and not in the main basin of the dam. Thirteen crocodiles were re-introduced into the dam during March 2007; however the August 2009 spotlight survey results indicated that none of these animals had survived.
\end{abstract}

Keywords: Crocodylus niloticus, numbers, size classes, density, distribution

\section{Introduction}

The Loskop Dam is situated on the Olifants River, approximately $32 \mathrm{~km}$ south (upstream) of the town of Groblersdal in the Mpumalanga province of South Africa (Fig. 1). Construction work on the Loskop Dam was completed in 1938 by the Department of Water Affairs and in 1979 the wall was raised to its current height of $54 \mathrm{~m}$ above the foundation (Loskop Irrigation Board, 2009).

Jacobsen (1984) stated that the substantial decline in the population of Nile crocodiles in the Loskop Dam was a cause for concern. Two main reasons for this decline had already been suggested in the early 1980s. The first hypothesized that pollution emanating from the upper reaches of the Olifants River catchment could have a detrimental effect on the reproductive potential of the crocodiles in the dam; the second suggested that the raising of the Loskop Dam resulted in flooding of basking and nesting areas making these unusable by crocodiles and thus reducing recruitment into the population (Jacobsen, 1984). The cause of periodic deaths of large numbers of crocodiles in the Loskop Dam has not been resolved over the last 26 years. Jacobsen (1984) warned that should the decline in crocodile numbers in the Loskop Dam be a result of pollution, then recovery was unlikely and re-introduction of crocodiles into the system would be pointless.

A growing body of literature clearly demonstrates that a wide array of contaminants, including pesticides, metals and nutrients, influences the growth and reproduction of aquatic

\footnotetext{
* To whom all correspondence should be addressed.

푱 +2713262 4844; fax: +2713 262 4858;

e-mail: nilecrocs@mweb.co.za

Received 18 May 2010; accepted in revised form 3 November 2010
}

organisms, including top predators such as crocodilians (Guillette and Crain, 2000; Milnes et al., 2006; Milnes and Guillette, 2008). Although at this time there is very limited data on contaminant effects in Nile crocodiles, the data on exposure levels (Phelps et al., 1986; Skaare et al., 1991) and physiological-molecular processes (Katsu et al., 2006) indicate that all the data published to date demonstrating adverse effects on the American alligator, and other crocodilians, are directly applicable. Thus, we have to consider the hypothesis that contaminants are, in large part, a threat to the maintenance of crocodilian populations in Africa, and further studies are needed to begin to test this hypothesis in greater detail. Further, in-depth observations of available nesting and basking sites must be catalogued at varying water levels so that a true representation of available recruitment can be made. The study described below represents the beginning of such research.

\section{Methods}

Surveys to determine the number, size and spatial distribution of the crocodiles in the Loskop Dam were performed using 2 methods: aerial counts from aircraft and spotlight counts from boats. In both types of survey, the total length (TL) of individual crocodiles encountered was estimated to the nearest metre and animals assigned to the following broad size classes:

- Class 1: Small-sized crocodiles (TL $<1.4 \mathrm{~m})$

- Class 2: Medium-sized crocodiles (TL 1.4-2.1 m)

- Class 3: Large-sized crocodiles (TL 2.1-4.0 m)

- Class 4: Very large-sized crocodiles (TL $>4.0 \mathrm{~m})$

The position of each crocodile counted was marked with a handheld Global Positioning System (GPS) and the TL noted with the waypoint number on a datasheet or palm computer and downloaded later to a notebook computer. 
It is known that reproductive maturity is more closely related to size (approximately $2 \mathrm{~m}$ ) than age in crocodilians (Cott, 1961; Graham, 1968; Whitworth, 1971; Joanen and McNease, 1975; Hutton, 1984; Games, 1990; Magnusson et al., 1990). Thus crocodiles in the small and medium size classes (less than $2.1 \mathrm{~m}$ TL) were grouped together as they are likely to be non-reproductive. Similarly, all crocodiles in the large size class (between 2.1 and $4.0 \mathrm{~m} \mathrm{TL}$ ) were grouped together, as they are likely to be the reproductive animals, whereas those over $4.0 \mathrm{~m}$ TL were a third distinct group as they are likely the large dominating males in the population.

The size (total length) of completely submerged crocodiles was estimated using specific environmental and behavioural characteristics. These included factors such as habitat type, water depth, water swirl, mud trails and wakes (Jacobsen, 1984; Woodward and Moore, 1993). According to Jacobsen (1984), the tendency to underestimate the size of crocodiles spotted from the air is regarded as a constant factor and can therefore be ignored. Economic reasons eventually necessitated that the crocodilian population surveys be conducted by spotlight counts rather than aerial counts. However, spotlight counts are regarded as a suitable and reliable method for estimating crocodilian population size (Webb and Messel, 1979; Bayliss et al., 1986; Hutton and Woolhouse, 1989; Games, 1990; Woodward and Moore, 1993). To account for the number of crocodiles missed by observers during surveys, correction factors were calculated and applied to the data according to methods described by Magnusson et al. (1978), Bayliss, et al. (1986), Hutton and Woolhouse (1989) and Stirrat et al. (2001).

\section{Results}

The survey data demonstrated a very low total number of crocodiles as well as a very poor distribution of crocodiles over the size classes, compared to that expected to be present in healthy populations. During 1979 a total of 21 crocodiles were counted in the Loskop Dam (Jacobsen, 1984). Taking the expected undercount into consideration (Bayliss 1987; Swanepoel, 2001; Botha, 2005), this translates to an estimated 32 animals that could have been present in the dam at the time of the survey. The February and August 2010 spotlight survey results (Table 1) indicate that the population is currently at an extremely low level with only 4 individual crocodiles found in the dam. Accounting for the expected undercount, we estimate the total Nile crocodile population in the Loskop Dam to be no more than 4 to 6 animals at this time. A total of 8 crocodiles were found in the whole of the Loskop Dam during the 2006 spotlight survey (Table 1). Previous surveys in 2001 and 2005 produced similar low results, of 10 and 6 animals, respectively. The brief increase registered during the July 2006 and January 2007 spotlight surveys is likely to be a function of the observers gaining experience rather than of a successful population increase.

Also of interest is that no crocodiles in the large (2.1-4.0 m) size class were found during the July 2006, January 2007, August 2007, August 2009, February 2010 or August 2010 surveys, whereas no crocodiles in the very large $(>4.0 \mathrm{~m})$ size class were found in any of the surveys from 2001 to 2010 (Table 1).

Although these surveys failed to locate any crocodiles in the over $4.0 \mathrm{~m}$ TL category, they did at least confirm the presence of 3 crocodiles in the $2.1-4.0 \mathrm{~m}$ size class during 2005. By July 2006, these large crocodiles also disappeared from the dam (Table 1). The current crocodile population density in the Loskop Dam is very low at 0.06 crocodiles $/ \mathrm{km}$ of shoreline (Table 1 ). The standard deviation of the population density is 0.06 (Table 1), indicating that over the time period of this study, population numbers did not deviate widely from the mean density and constantly remain at a lowel. During the 2001 and 2005 aerial surveys, as well as the 2006, 2007, 2009 and 2010 spotlight surveys, crocodiles were found in the Olifants River around the western inlets of the dam and also in the area of the eastern inlets of the dam at the Kranspoortspruit and Scheepersloop areas (Fig. 1).

\begin{tabular}{|c|c|c|c|c|c|c|c|c|c|c|}
\hline \multicolumn{11}{|c|}{$\begin{array}{c}\text { Table } 1 \\
\text { Summary of the numbers, size distribution and density (crocs/km) of Nile crocodiles in the Loskop Dam, Olifants River, } \\
\text { Mpumalanga province }\end{array}$} \\
\hline \multirow[t]{2}{*}{ Survey year } & \multirow[t]{2}{*}{ Type of survey } & \multicolumn{5}{|c|}{ Size class } & \multirow{2}{*}{$\begin{array}{c}\text { Total } \\
\text { number }\end{array}$} & \multirow{2}{*}{$\begin{array}{l}\text { Estimated } \\
\text { number }\end{array}$} & \multirow{2}{*}{\begin{tabular}{|c|}
$\begin{array}{c}\text { Number } \\
\text { re- } \\
\text { introduced }\end{array}$ \\
\end{tabular}} & \multirow{2}{*}{$\begin{array}{c}\text { Density } \\
\text { (crocodiles/ } \\
\text { km) }\end{array}$} \\
\hline & & $<1.4 \mathrm{~m}$ & $\begin{array}{c}1.4-2.1 \\
\mathrm{~m}\end{array}$ & $\begin{array}{c}2.1-4.0 \\
\mathrm{~m}\end{array}$ & $>4.0 \mathrm{~m}$ & Unsure & & & & \\
\hline $1981^{\#}$ & Aerial survey & 0 & 2 & 3 & 1 & 0 & 6 & 9 & 0 & 0.09 \\
\hline 2001 & Aerial survey & 1 & 0 & 9 & 0 & 0 & 10 & 15 & 0 & 0.14 \\
\hline December 2005 & Aerial survey & 2 & 1 & 3 & 0 & 0 & 6 & 9 & 0 & 0.09 \\
\hline July 2006 & Spotlight survey & 7 & 1 & 0 & 0 & 0 & 8 & 12 & 0 & 0.11 \\
\hline January 2007 & Spotlight survey & 6 & 4 & 0 & 0 & 2 & 12 & 18 & 0 & 0.17 \\
\hline August 2007 & Spotlight survey & 7 & 7 & 0 & 0 & 2 & 16 & 25 & 13 & 0.23 \\
\hline August 2009 & Spotlight survey & 2 & 7 & 0 & 0 & 1 & 10 & 15 & 0 & 0.14 \\
\hline February 2010 & Spotlight survey & 1 & 3 & 0 & 0 & 0 & 4 & 6 & 0 & 0.06 \\
\hline August 2010 & Spotlight survey & 0 & 2 & 0 & 0 & 2 & 4 & 6 & 0 & 0.06 \\
\hline \multicolumn{2}{|c|}{ Total of all surveys } & 26 & 27 & 15 & 1 & 7 & 76 & 115 & 13 & - \\
\hline \multicolumn{2}{|c|}{ Mean of all surveys } & 3 & 3 & 2 & 0 & 1 & 8 & 13 & - & 0.12 \\
\hline \multicolumn{2}{|c|}{ Standard deviation } & 2.93 & 2.55 & 3.04 & 0.33 & 0.97 & 3.97 & 6.20 & - & 0.06 \\
\hline
\end{tabular}

$\#=$ Jacobsen (1984) 


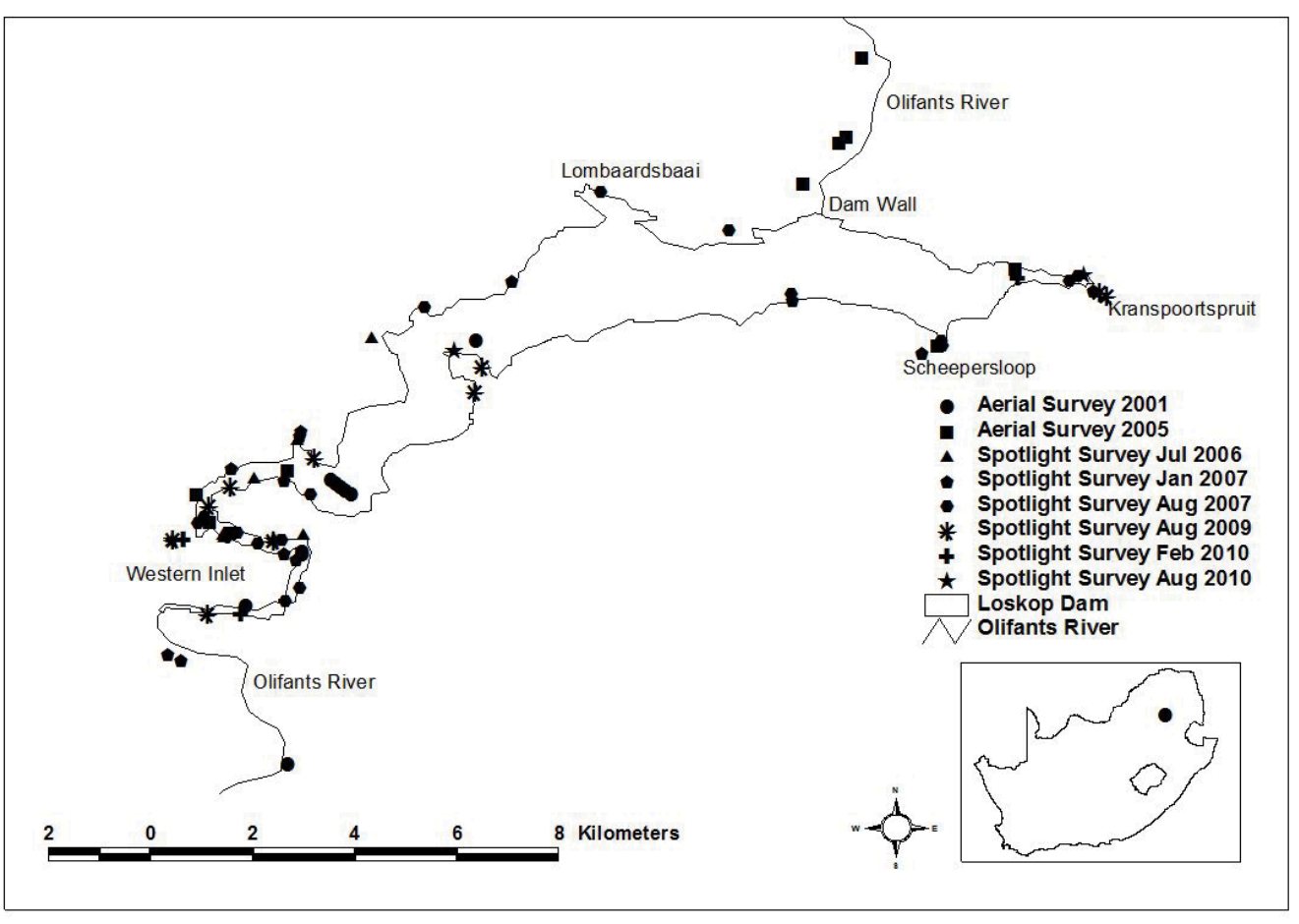

The 8 surveys conducted since 2001 revealed that the distribution pattern of crocodiles in the Loskop Dam did not vary between winter and summer. Thirteen crocodiles, all between 1.09 and $1.86 \mathrm{~m} \mathrm{TL}$, were re-introduced during March 2007. This caused an artificial increase in the number of crocodiles present in the dam during the August 2007 spotlight survey, but the results of the August 2009, February 2010 and August 2010 spotlight surveys clearly show that none of these reintroduced animals survived longer than 2 years (Table 1).

The 1981 population structure reported by Jacobsen (1984) indicates that the segment of the population consisting of small- and medium-sized crocodiles (all crocodiles less than $2.1 \mathrm{~m} \mathrm{TL}$ ) was smaller in number than the large size class which consists of crocodiles between 2.1 and $4.0 \mathrm{~m}$ TL (Table 1). Our data indicate that in 2001 and 2005 no crocodiles in the over $4.0 \mathrm{~m}$ TL size class were present in the Loskop Dam population and this size class was still absent during the 2006, 2007, 2009 and 2010 surveys (Table 1). However, the results of the 2006, 2007, 2009 and 2010 surveys also indicated that all crocodiles in the 2.1-4.0 m TL size class were also absent from this population, leaving only the small and medium size classes intact and suggesting that either some recruitment (e.g. reproduction had occurred in the previous few years) had taken place or that younger animals had immigrated into the dam from upstream. This has created a highly skewed population structure which differs substantially from that expected in a healthy crocodilian population.

\section{Discussion}

Crocodilian populations have been studied worldwide, as most wild populations today are under serious threat due to habitat loss, degradation and pollution (Pooley, 1969; Jacobsen, 1988; Ross, 1998; Campbell, 2006; MacGregor, 2006). Although these large predators are perceived by many as non-essential members of healthy aquatic ecosystems, they are actually keystone and sentinel species that can provide information on the long-term health of an ecosystem. The data reported here clearly indicate that the Nile crocodile population in the Loskop Dam is not healthy, nor has it been for decades. The underlying reasons for this are still not fully understood and require further investigation, but our data have established that the population structure and distribution of these animals is not normal. It is important to recognize that, for these long-lived organisms, 1 or 2 surveys of a population cannot easily predict the health of that population, but the combination of this survey data with that of earlier studies can be conclusive and demonstrates that the population at Loskop Dam is not healthy. In turn, these data suggest that the Olifants River system in general, of which this dam is but a part, also has major problems that must be addressed. Finally, our data suggest that if the underlying problem with the crocodile population at Loskop Dam is more than just the loss of nesting sites, and this seems reasonable given our data, then other aquatic species in this ecosystem are also likely impacted, as crocodilians do serve as an effective sentinel species for other vertebrates.

The low total number of individuals encountered during the 2006 and 2009 surveys corresponds closely with the numbers recorded during the 2001 and 2005 surveys. More importantly, the low number of animals in general, and in particular the numbers from 2006 which are virtually the same as the result of the 1981 survey (Jacobsen, 1984), and the very low numbers from the 2010 surveys, indicate that recruitment via reproduction or immigration from the Olifants River system into the dam has been almost nonexistent for decades. That is, population size has not changed noticeably upward over the preceding 25 years and the observed decline in population numbers over the long-term is not a function of a naturally fluctuating population or poor census techniques.

Given the reintroduction of 3 crocodiles during 1983/1984 (Transvaal Nature Conservation Division, 1985), 6 crocodiles during 1984/1985 (Transvaal Nature Conservation Division, 
1986) and 13 crocodiles in 2007, the population should have shown at least some increase over the 25 year period. Moreover, given that these were adults introduced into the population, one would expect some population increase in the small size class animals if recruitment via reproduction was occurring. However, the survey results indicate that the population did not increase, even though a few smaller animals are now seen. In short, recruitment of this population is not overcoming the death or emigration rate.

The mean population density of the current crocodile population in Loskop Dam equates to 0.12 crocodiles $/ \mathrm{km}$ of shoreline. However, the entire shoreline is not good habitat for basking, nesting and other behaviours. In contrast, a much greater proportion of the shore provided good habitat in earlier years, prior to the dam wall being raised in 1979. Historical records show that human settlement of the area where the dam is located started as long ago as 1886 (Loskop Irrigation Board, 2009), when crocodiles were abundant along the entire Olifants River. In spite of the experimental re-introduction of 13 adult animals into the population during 2007 , the overall density trend seems to indicate that the population has remained at a very low level since 1981. The standard deviation for the population density from all surveys is 0.06 indicating that the annual population density figures do not deviate much from the mean value. Therefore, although the total counts fluctuate from year to year, the population density remains at a very low level. The low density of crocodiles in Loskop Dam has been an ongoing issue for over 25 years. When compared to other crocodilian populations in similar habitats (i.e. living in water storage reservoirs or lakes), the low population density of the Loskop Dam stands out as unique. The Flag Boshielo Dam, situated $85 \mathrm{~km}$ downstream from the Loskop Dam, on the Olifants River, has a density of 3.25 crocodiles/ $\mathrm{km}$ of shoreline (Botha, 2005). The Olifants River in the Kruger National Park has a density of 3.98 crocodiles $/ \mathrm{km}$ of shoreline whereas the Olifants River Gorge in the lower reaches of the Olifants River within the Kruger National Park has a very high density of 30 crocodiles $/ \mathrm{km}$ of shoreline (Botha, 2005).

In addition to the stationary nature of the population, no hatchling crocodiles (animals less than 1 year old) were found during the 2006, 2007, 2009 or 2010 spotlight surveys (no survey was performed in 2008). Recruitment into the Loskop Dam crocodile population is therefore seriously compromised. Only 1 animal in the $>4.0 \mathrm{~m}$ size class was reported during the 1981 survey and no animals in this size class have been recorded during any of the subsequent surveys. These very large animals are the dominant animals necessary for normal competition, behaviour and successful nesting in any population (Lang, 1987; Lang, 1990) and it is possible that the absence of this size class in a wild population will hamper that population's chances of expanding normally. The disappearance of the large animals from the population is unlikely to be linked to the lack of nesting areas or even food, which is plentiful, because one would then expect the small crocodiles to disappear first because no recruitment had taken place or because they could not compete for food. The survey data (Table 1) reveal that this did not happen; that is, the largest animals disappeared from the population first. A further concern is the lack of animals observed in the 2.1-4.0 $\mathrm{m}$ TL size class during the 2006, 2007, 2009 and 2010 surveys. If, as we have noted, the animals in the $>4.0 \mathrm{~m}$ TL size class are absent from the population, then it is expected that the next size class, those animals that are sexually mature and in the 2.1-4.0 m TL class, will 'stand in' for the absent dominant animals. However, if they too are now absent from the population, which our data suggest, then the concern expressed by Jacobsen (1984) would appear to be well-founded, and there is a distinct possibility that this population will become extinct.

The distribution pattern of the crocodiles in Loskop Dam indicates that most of the crocodiles observed occurred in the river-like area at the inlet of the Olifants River to the dam. This is possibly due to the higher water levels, caused by the raising of the dam wall, and which has rendered the vast majority of all the other shoreline areas in the dam unsuitable for crocodiles. The impact of this is that the population is now concentrated in those areas where the possible effects of pollution from the inflowing river are likely far worse than anywhere else in the dam, due to the dilution effect of the main water body in the dam (Oberholster et al., 2010). Therefore the altered spatial distribution of crocodiles, caused by the loss of suitable habitat as a result of the raising of the dam wall, has placed them in an area where they would likely experience higher levels of pollution than elsewhere in the dam. As ingestion and drinking are likely the major routes of exposure to contaminants in crocodilians, it is likely that the crocodile's food source, which inhabits this same area, contributes towards placing them in areas at risk of pollution. This could very well be a critical factor in the episodes of periodic die-off of crocodiles that have been witnessed in Loskop Dam.

The results of 8 surveys carried out since 2001 show that the distribution pattern of crocodiles in Loskop Dam does not vary between winter and summer periods. Distribution patterns and movements in crocodilian populations are usually associated with important population milestones, such as the onset of mating and nesting during the summer months. Definite seasonal distribution patterns are known to occur in the larger Nile crocodile population of the Flag Boshielo Dam downstream from the Loskop Dam (Botha, 2005). The total absence of any seasonal variation in the distribution of the Loskop Dam crocodile population supports the hypothesis that no crocodiles in the large and very large size class currently occur in the Loskop Dam. It also indicates that important behaviour and population milestones do not now occur in the Loskop Dam population, and indicate that this is an unstable population, unlikely to survive if current conditions persist into the future.

\section{Conclusion}

The total number of Nile crocodiles in the Loskop Dam has declined over the last 25 to 30 years. As importantly, there are now no surviving large animals over $2.1 \mathrm{~m}$ TL in the entire Loskop Dam population; this presents a crisis for future breeding seasons as animals of this size represent the sexually mature animals in the population. Surveys confirm the complete absence of any dominant animals in the population since at least 2001. The recorded crocodile die-off events between 2005 and 2007 have further depleted the Nile crocodile population in this aquatic system. Crocodile mortalities in the Loskop Dam during this period have been ascribed to pansteatitis, which is associated with the intake of rancid fish after several fish die-off events, which appears to have resulted from cumulative impacts of acid mine drainage 
into the dam (Holman, 2008; Paton, 2008; Oberholster et al., 2010). Water quality monitoring in the Olifants River indicates that the quality of the water has deteriorated since the 1970s as a result of industrial, mining and agricultural activities (De Villiers and Mkwelo, 2009). Therefore, it is likely that the current-day distribution pattern of crocodiles in the river inflow zone of Loskop Dam exposes them to a wide array of contaminants and likely a more concentrated mix of pollutants than they would experience in the main body of the dam where pollutants would be more diluted. However, it is important to note that dermal exposure is not the likely route of contaminant intake; rather a diet of contaminated fish and other vertebrates from this same ecosystem would contribute to the contamination of this top predator. However, this hypothesis must be verified by further study. It is clear that the experimental re-introduction of crocodiles to the population has failed to stabilise or contribute to its growth and similar re-introductions should not be considered while current conditions in Loskop Dam persist.

\section{Acknowledgements}

We thank the Mpumalanga Tourism and Parks Agency, the Centre for Wildlife Management at the University of Pretoria and Koos de Wet for assistance with this project. We thank Peter Ashton of the CSIR for providing suggestions that improved an early draft of this manuscript.

\section{References}

BAYLISS P, WEBB GJW, WHITEHEAD PJ, DEMPSEY K and SMITH A (1986) Estimating the abundance of saltwater crocodiles, Crocodylus porosus Schneider, in tidal wetlands of the Northern Territory: a mark-recapture experiment to correct spotlight counts to absolute numbers and the calibration of helicopter and spotlight counts. Aust. Wildl. Res. 13 309-320.

BAYLISS P (1987) Survey methods and monitoring within crocodile management programmes. In: Webb GJW, Manolis SC and Whitehead PJ (eds.) Wildlife Management: Crocodiles and Alligators. Surrey Beatty and Sons, Chipping Norton.

BOTHA PJ (2005) The ecology and population dynamics of the Nile crocodile Crocodylus niloticus in the Flag Boshielo Dam, Mpumalanga province, South Africa. M.Sc. Thesis. University of Pretoria.

CAMPBELL TW (2006) Clinical pathology of reptiles. In: Mader DR (ed.) Reptile Medicine and Surgery $\left(2^{\text {nd }}\right.$ edn.). Saunders Elsevier, St Louis.

COTT HB (1961) Scientific results of an inquiry into the ecology and economic status of the Nile crocodile (Crocodylus niloticus) in Uganda and Northern Rhodesia. Proc. Zool. Soc. London 29 211-256.

DE VILLIERS S and MKWELO ST (2009) Has monitoring failed the Olifants River, Mpumalanga? Water SA 35 (5) 671-676.

GAMES I (1990) Growth curves for the Nile crocodile as estimated by skeleton-chronology. Proc. $10^{\text {th }}$ Working Group Meeting of the Crocodile Specialist Group of the Species Survival Commission of IUCN. IUCN. Gland, Switzerland.

GRAHAM A (1968) The Lake Rudolf crocodile (Crocodylus niloticus Laurenti) population. Unpublished Report, Kenya Game Department, Nairobi.

GUILLETTE LJ Jr. and CRAIN DA (eds.) (2000) Endocrine Disrupting Contaminants: An Evolutionary Perspective. Taylor and Francis, Inc., Philadelphia.

HOLMAN J (2008) Coal giant recognises water management responsibility. Engineering News Online, 18 July 2008. URL: http://www. engineeringnews.co.za (Accessed 14 April 2010).

HUTTON JM (1984) The population ecology of the Nile crocodile, Crocodylus niloticus Laurenti, 1768, at Ngezi, Zimbabwe. Ph.D. Thesis, University of Zimbabwe, Harare.
HUTTON JM and WOOLHOUSE MEJ (1989) Mark-recapture to assess factors affecting the proportion of a Nile crocodile population seen during spotlight counts at Ngezi, Zimbabwe and the use of spotlight counts to monitor crocodile abundance. J. Appl. Ecol. 26 381-395.

JACOBSEN NHG (1984) The distribution and status of crocodile populations in the Transvaal outside the Kruger National Park. Biol. Conserv. 29 191-200.

JACOBSEN NHG (1988) The Nile crocodile. In: Branch WR (ed.) South African red data book - reptiles and amphibians. South African National Scientific Report No. 151. CSIR, Pretoria.

JOANEN T and McNEASE L (1975) Notes on the reproductive biology and captive propagation of the American alligator. Proc. Ann. Conf. Southeastern Assoc. Game and Fish Comm. 29 407-415.

KATSU Y, MYBURGH J, KOHNO S, SWAN G E, GUILLETTE LJ Jr. and IGUCHI T (2006) Molecular cloning of estrogen receptor $\alpha$ of the Nile crocodile. Comp. Biochem. Physiol. Part A: Mol. Integr. Physiol. 143 340-346.

LANG JW (1987) Crocodilian behaviour: Implications for management. In: Webb GJW, Manolis SC and Whitehead PJ (eds.) Wildlife Management: Crocodiles and Alligators. Surrey Beatty and Sons, Chipping Norton.

LANG JW (1990) Social behaviour. In: Ross CA (ed.) Crocodiles and Alligators. Merehurst Press, London.

LOSKOP IRRIGATION BOARD (2009) Loskop water scheme. Loskop Irrigation Board, Groblersdal. URL: http://www.loskopbesproeingsraad.co.za (Accessed 2 April 2009).

MACGREGOR J (2006) The call of the wild: Captive crocodilian production and the shaping of conservation incentives. TRAFFIC International, Cambridge.

MAGNUSSON WE, CAUGHLEY GJ and GRIGG GC (1978) A double-survey estimate of population size from incomplete counts. J. Wildl. Manage. 42 (1) 174-176.

MAGNUSSON WE, VLIET KA, POOLEY AC and WHITAKER R (1990) Reproduction. In: Ross CA (ed.) Crocodiles and Alligators. Merehurst Press, London.

MILNES MR, BERMUDEZ DS, BRYAN TA, EDWARDS TM, GUNDERSON M P, LARKIN IV, MOORE BC and GUILLETTE LJ Jr. (2006) Contaminant-induced feminization and demasculinization of nonmammalian vertebrate males in aquatic environments. Environ. Res. 100 3-17.

MILNES MR and GUILLETTE LJ Jr. (2008) Alligator tales: New lessons about environmental contaminants from a sentinel species. Biosci. 58 (11) 1027-1036.

OBERHOLSTER PJ, MYBURGH JG, ASHTON PJ and BOTHA A-M (2010) Responses of phytoplankton upon exposure to a mixture of acid mine drainage and high levels of nutrient pollution in Lake Loskop, South Africa. Ecotoxicol. Environ. Saf. 73 (1) 326-335.

PATON C (2008) Dam dirty. Financial Mail 28 November 2008. 32-39.

PHELPS RJ, FOCARDI S, FOSSI C, LEONZIO C and RENZONI A (1986) Clorinated hydrocarbons and heavy metals in crocodile eggs from Zimbabwe. Trans. Zimb. Sci. Assoc. 63 8-15.

POOLEY AC (1969) Preliminary studies on the breeding of the Nile crocodile Crocodylus niloticus in Zululand. Lammergeyer 10 22-44.

ROSS JP (ed.) (1998) Crocodiles. Status Survey and Conservation Action Plan ( $2^{\text {nd }}$ edn.). IUCN/SSC Crocodile Specialist Group. IUCN, Gland, Switzerland.

SKAARE JU, INGEBRIGTSEN K, AULIE A and KANUI TI (1991) Organochlorines in crocodile eggs from Kenya. Bull. Environ. Contam. Toxicol. 47 126-130.

STIRRAT SC, LAWSON D, FREELAND WJ and MORTON R (2001) Monitoring Crocodylus porosus populations in the Northern Territory of Australia: a retrospective analysis. Wildl. Res. $\mathbf{2 8}$ 547-554.

SWANEPOEL DGJ (2001) The raising of the Arabie Dam wall and the impacts on the Nile crocodile population. Unpublished Report, Department of Water Affairs and Forestry, Pretoria, South Africa.

TRANSVAAL NATURE CONSERVATION DIVISION (1985) Nineteenth Annual Report: 1983/84. Transvaal Provincial Administration, Pretoria. 
TRANSVAAL NATURE CONSERVATION DIVISION (1986)

Twentieth Annual Report: 1984/85. Transvaal Provincial Administration, Pretoria.

WEBB GJW and MESSEL H (1979) Wariness in Crocodylus porosus. Aust. Wildl. Res. 6 227-234.

WHITWORTH J (1971) Notes on the growth and mating of American alligators Alligator mississippiensis at the Cannon Aquarium,
Manchester Museum. Int. Zoo Yearbook 11144.

WOODWARD AR and MOORE CT (1993) Use of crocodilian night count data for population trend estimation. Proc. $2^{\text {nd }}$ Regional Conference of the Crocodile Specialist Group, Species Survival Commission, IUCN, 12-13 March 1993, Darwin, Australia. 